\title{
Analysis of prescription database extracted from standard textbooks of traditional Dai medicine
}

\author{
Chuang Zhang ${ }^{1,2^{*}}$, Virasakdi Chongsuvivatwong ${ }^{2}$, Niwat Keawpradub ${ }^{3}$ and Yanfang Lin ${ }^{4}$
}

\begin{abstract}
Background: Traditional Dai Medicine (TDM) is one of the four major ethnomedicine of China. In 2007 a group of experts produced a set of seven Dai medical textbooks on this subject. The first two were selected as the main data source to analyse well recognized prescriptions.

Objective: To quantify patterns of prescriptions, common ingredients, indications and usages of TDM.

Methods: A relational database linking the prescriptions, ingredients, herb names, indications, and usages was set up. Frequency of pattern of combination and common ingredients were tabulated.

Results: A total of 200 prescriptions and 402 herbs were compiled. Prescriptions based on "wind" disorders, a detoxification theory that most commonly deals with symptoms of digestive system diseases, accounted for over one third of all prescriptions. The major methods of preparations mostly used roots and whole herbs.

Conclusion: The information extracted from the relational database may be useful for understanding symptomatic treatments. Antidote and detoxification theory deserves further research.
\end{abstract}

Keywords: Traditional Dai medicine, Dai medical textbooks, Dai prescription

\section{Background}

\section{Dai minority and traditional Dai medicine}

In China, traditional Dai Medicine (TDM), one system of ancient ethnomedicine, has accumulated more than 2,500 years of experience in the process of struggling with the treatment of diseases [1]. It has absorbed and integrated practices from Indian medicine, Hinayana Buddhism and local wisdom to form a unique medical theory. In 1984, the government of China defined TDM as one of China's four important systems of ethnomedicine. The other three are from Tibetan, Mongolian and Uygur origins [2].

Dai people have their own unique language which belongs to the Tai-Lao family. Its alphabet is derived from the ancient Indian alphabet. Dai people mainly inhabit the southern part of Yunnan province of China,

\footnotetext{
* Correspondence: Jack.Zh.Ch@gmail.com

${ }^{1}$ Faculty of Ethnomedicine, Yunnan University of Traditional Chinese Medicine, No. 1076 Yuhua Road, Chenggong, Kunming, Yunnan Province 650500, China

2Epidemiology Unit, Faculty of Medicine, Prince of Songkla University, HatYai, Songkhla 90110, Thailand

Full list of author information is available at the end of the article
}

but there are significant populations living also in Myanmar, Laos, northern Thailand and Vietnam.

In the past, the main-stream culture and education was obtained through temples. The temple-based education system maintains and integrates religion, written language, values, native perception, mythology and medicine. The inheritance of TDM has two different ways. One is passing down from generation to generation by oral communication and learned by heart. The other is for the literate people learning from documents such as "Tam Lan" (the sutra carved on the palm leaves by Buddhists), which are the media for both TDM and Hinayana Buddhism [3].

Although TDM has accumulated a wealth of medical knowledge and related works, it is gradually vanishing due to the impact and prevalence of western medicine and modern hospitals [3].

In 2004, in order to preserve TDM and train more Dai medical professionals, the State Administration of Traditional Chinese Medicine (TCM) of China set up a project named " $21^{\text {st }}$ century general higher educational teaching material of TDM" and entrusted the Yunnan Provincial Department of Health to organize

\section{Biomed Central}


relevant units and experts to compile it. Famous experts ("Famous" is a high ranking title) and professors in related fields throughout China were invited to form an academic council, the members of which included the last king of Dai nationality, Famous Old Traditional Dai doctors (TDD), academicians of pharmacy and Famous TCM doctors. Finally, the Ethnomedicine Research and Development Center of Yunnan University of TCM and Xishuangbanna Dai Medical Hospital coordinated and completed the project. Consequently since 2007, a set of seven Dai medical textbooks, published by Chinese Publishing House of TCM, has been used as the general higher educational teaching materials for the undergraduates whose major is TDM. The textbooks include Formulas of Dai Medicine (Book A) [4], Dai Materia Medica (Book B) [5], Basic Theories of Dai Medicine (Book C) [6], Diagnostics of Dai Medicine (Book D) [7], Clinical Dai Medicine, History of Dai Medicine and Selected Readings of Dai Medicinal Classic. This first set of Dai medical undergraduate textbooks is the most authoritative Dai medical monographs of TDM of China at present.

\section{Brief introduction to traditional Dai medicine theory}

TDM theory has its own unique characteristics. "Ta Du Dang Si" Theory (TDDST or caturmahabhuta) and "Han Ta Dang Ha" Theory (HTDHT or skandha) are the core theories. TDDST regards the body as being formed by four cosmic elements including wind, fire, water and earth. Disharmony of these elements gives rise to pain and disease while harmony results in good health. HTDHT refers to form, consciousness, feeling, perception and intention to explain the physiological structure, phenomena and spiritual activities of the body $[1,6]$.

"Ya Gei" theory (YGT or Detoxification theory) is a unique supplementary theory of TDM. Its core content is to "detoxify before a disease commences and treat a disease after detoxification". TDM believes that all materials which can enter the human body, including food, can produce certain poisonous effects to the body if they are consumed excessively. In order to keep healthy, people must take antidotes regularly to eliminate these micro toxins, and thus reduce the chance of illness and prolong life [6].

Therefore, Dai medicinal theory believes that in the process of daily life, all kinds of internal and external pathogenic factors may lead to imbalance of four cosmic elements and produce some toxins, consequently generating disorders of physiological functions. However, antidotes could be used for release of toxins and adjustments of physiological functions. Therefore, keep the balance of functions of four elements can reduce illness and death [6].

The fact that prescription data are systematically recorded in the books affords us an opportunity to analyse and gain better insights into how TDM makes use of the existing herbs in their medicine. The objectives of this study are to extract and analyse main information from these standard textbooks and quantify the patterns of prescriptions, indications and preparations.

\section{Materials and methods \\ Data source}

Books A and B were related to prescriptions and herbs, so these were selected as the main data source. Books $C$ and $\mathrm{D}$ did not contribute to the database, but could provide terminology, concept and theory, and were therefore used in explanation of the relationship among variables in the database.

\section{Prescriptions}

Each prescription involves the name, ingredients, indications, dosage and method of preparation. The names were already transliterated and paraphrased into the Han (Chinese) language.

\section{Indications}

The indications of prescriptions are described with either modern disease names, or syndrome and symptoms. We did initial verbatim translation to English. However, it was obvious that certain diseases were interpreted by an editor with a western medicine concept, e.g. urinary disease, immune disease etc. The disease names were therefore omitted. Only the indications such as common symptoms and syndromes were included.

Table 1 The top eleven most widely applied prescriptions

\begin{tabular}{lll}
\hline Prescription name & $\begin{array}{l}\text { Number of } \\
\text { indications }\end{array}$ & Attribution \\
\hline Ya-Peng-Leng & 10 & Wind \\
Ya-Peng-Lang & 9 & Wind \\
Ya-Gei-Shuang-Long & 8 & Antidote \\
Fei-Mai-Nan-Huang-Luo & 8 & Antidote \\
Ya-Gei-Na-Er & 7 & Fire \\
Ya-Gei-Sa-Ba & 7 & Antidote \\
Ya-Gei-Bi & 7 & Antidote \\
Ya-Nuan-Long-Lan-Shen & 6 & Wind \\
Ya-Dong-Hong & 6 & Wind \\
Ya-Sha-Long-Jie-Huo & 6 & Fire \\
Ya-Xi-Li-Meng-La-Ga-Han & 6 & Antidote \\
\hline
\end{tabular}


Table 2 Attributions and preparations of the prescribed ingredients

\begin{tabular}{lcccccccc}
\hline Attribution Preparation & All elements & Wind & Fire & Water & Earth & Antidote & Others & Total (\%) \\
\hline Decoction (\%) & $3(0.5)$ & $117(20.4)$ & $128(22.3)$ & $153(26.7)$ & $134(23.3)$ & $31(5.4)$ & $8(1.4)$ & $574(62.8)(100)$ \\
Powder (\%) & $29(19.2)$ & $54(35.8)$ & $10(6.6)$ & $5(3.3)$ & $20(13.2)$ & $0(0)$ & $33(21.9)$ & $151(16.5)(100)$ \\
Pill (\%) & $15(19.5)$ & $3(3.9)$ & $14(18.2)$ & $6(7.8)$ & $9(11.7)$ & $24(31.2)$ & $6(7.8)$ & $77(8.4)(100)$ \\
Vinum (\%) & $4(8.5)$ & $21(44.7)$ & $7(14.9)$ & $0(0)$ & $0(0)$ & $0(0)$ & $15(31.9)$ & $47(5.1)(100)$ \\
Sleeping on heated herbs (\%) & $0(0)$ & $32(100)$ & $0(0)$ & $0(0)$ & $0(0)$ & $0(0)$ & $0(0)$ & $32(3.5)(100)$ \\
Taking juice(\%) & $0(0)$ & $0(0)$ & $2(11.8)$ & $6(35.3)$ & $2(11.8)$ & $2(11.8)$ & $5(29.4)$ & $17(1.9)(100)$ \\
Boiling with meat (\%) & $0(0)$ & $2(12.5)$ & $5(31.2)$ & $3(18.8)$ & $6(35.3)$ & $0(0)$ & $0(0)$ & $16(1.8)(100)$ \\
Total (\%) & $51(5.6)$ & $229(25.1)$ & $166(18.2)$ & $173(18.9)$ & $171(18.7)$ & $57(6.2)$ & $67(7.3)$ & $914(100)(100)$ \\
\hline
\end{tabular}

\section{Ingredients}

The names of the ingredients were listed both in Dai and Han. Regardless of the availability of the botanical names, all ingredient names were put into the database.

\section{Plant parts}

If the information on plant parts was not available in Book A we used the information about plant parts recorded in Book B which was a monograph of Dai medicinal plants.

\section{Coding and computerization}

Each indication/symptom/disease name/ herb/ medicinal part was given a unique code according to the following principles:

1) Synonyms were given the same code

2) Redundant or non-symptom information was deleted

3) Long descriptive words were simplified

After data entry by the first author, two other persons randomly checked $40 \%$ of the selected data to minimize the errors.

\section{Relational structure of the database}

The different components of herbs could also be used in multiple prescriptions, preparations and dosages. The information was computerized in a relational database. The major fields included prescriptions name, composition, herbs, indications, medicinal parts, attributions, and usages.

\section{Data analysis}

The frequency/proportion of medicinal parts and preparations was summarized by tabulation. The frequency of occurrence of herbs, prescriptions and indications was calculated in percentage. Only those with relatively high frequencies were selected and listed in tables in this article.

\section{Results and discussion}

\section{Prescriptions, preparations and attributions}

According to TDM theory from Books C and D, components of Dai prescriptions can be categorized into principal ingredients, assistant ingredients, inhibiting ingredients, harmonizing ingredients and efficacyenhancing ingredients. According to their different roles and effects in the prescriptions, they can restrain each other and, therefore, enhance the impact and reduce the side effects and toxicity. In addition, both ingredients and prescriptions have different attributions, and each of them at least belongs to one element, so they could be used to against specific symptoms or disorders [4]. After reasonable combination, they could be used to rectify

Table 3 Most common symptoms/indications of prescriptions

\begin{tabular}{|c|c|}
\hline Symptom & Frequency \\
\hline Abdominal pain & 55 \\
\hline Fatigue/Lassitude & 43 \\
\hline Soft or liquid stool ${ }^{\boldsymbol{\Lambda}}$ & 36 \\
\hline Weakness & 33 \\
\hline Dark urine & 29 \\
\hline Stomachache ${ }^{\mathbf{\Delta}}$ & 29 \\
\hline Abdominal distension & 29 \\
\hline Vomiting $^{\wedge}$ & 29 \\
\hline Dry and hard stool ${ }^{\boldsymbol{\Delta}}$ & 29 \\
\hline Dry mouth & 28 \\
\hline No appetite & 27 \\
\hline Yellow and greasy furred tongue* & 25 \\
\hline White, greasy and thick furred tongue* & 23 \\
\hline Pale face & 23 \\
\hline Fever & 23 \\
\hline Heart palpitation & 20 \\
\hline Dizziness & 20 \\
\hline Nausea & 20 \\
\hline
\end{tabular}

Note: * The symptom was probably influenced by the interpretation of TCM experts included in the textbook editing. ${ }^{\Delta}$ The symptom related to gastro-intestinal disease. 
Table 4 Most commonly used medicinal plants

\begin{tabular}{|c|c|c|c|c|c|}
\hline Local name & Botanical name & Attribution(s) & Application or indications & Preparation(s) & Frequency (\%) \\
\hline Biu Biu Liang & $\begin{array}{l}\text { Plumbago } \\
\text { indica L. }\end{array}$ & $\begin{array}{l}\text { Fire, wind } \\
\text { and water }\end{array}$ & $\begin{array}{l}\text { Whole herb used for arthritis/ } \\
\text { joint pain, abnormal menstruation, } \\
\text { menstrual colic, cough, asthma, } \\
\text { weakness, impotence. }\end{array}$ & $\begin{array}{l}\text { Soup obtained from } \\
\text { whole herb deposited } \\
\text { in alcohol or after } \\
\text { decoction to be } \\
\text { taken orally. }\end{array}$ & $24(12.0)$ \\
\hline Hao Ming & $\begin{array}{l}\text { Curcuma } \\
\text { longa L. }\end{array}$ & $\begin{array}{l}\text { Water, earth } \\
\text { and wind }\end{array}$ & $\begin{array}{l}\text { Rhizome used for arthralgia, } \\
\text { traumatic injury, distending } \\
\text { pain of chest and abdomen, } \\
\text { amenorrhea, irregular menstruation, } \\
\text { swollen sores and furuncle, insect bites. }\end{array}$ & $\begin{array}{l}\text { Soup or juice of } \\
\text { Rhizome obtained } \\
\text { after decoction or } \\
\text { juicing to be } \\
\text { taken orally. }\end{array}$ & $20(10.0)$ \\
\hline Pi Nuai & Piper nigrum L. & Fire & $\begin{array}{l}\text { Fruit used for abdominal pain, } \\
\text { toothache, cough, asthma, } \\
\text { diarrhea, nausea and vomiting. }\end{array}$ & $\begin{array}{l}\text { Fruit made into } \\
\text { powder or soup } \\
\text { obtained from } \\
\text { decoction to be } \\
\text { taken orally. }\end{array}$ & $19(9.5)$ \\
\hline $\begin{array}{l}\text { Wen } \\
\text { Shang Hai }\end{array}$ & $\begin{array}{l}\text { Arundina } \\
\text { graminifolia } \\
\text { (D. Don) Hochr. }\end{array}$ & Water & $\begin{array}{l}\text { Bulb and whole herb used for the } \\
\text { deficiency of Qi and blood due } \\
\text { to postpartum, poisoning of food, } \\
\text { epilepsy, damp-heat jaundice. }\end{array}$ & $\begin{array}{l}\text { Soup of bulb and } \\
\text { whole herb obtained } \\
\text { from decoction to } \\
\text { be taken orally. }\end{array}$ & $17(8.5)$ \\
\hline Guan Di & Vitex trifolia L. & Wind and water & $\begin{array}{l}\text { Fruit and leaf used for dizziness, } \\
\text { poor vision, hemiplegia, } \\
\text { red swelling and pain of joints, } \\
\text { spasm and pain of extremities, } \\
\text { muscle and bone pain. }\end{array}$ & $\begin{array}{l}\text { Soup of fruit or leaf after } \\
\text { decoction to be taken orally. }\end{array}$ & $17(8.5)$ \\
\hline Han Hao Nan & $\begin{array}{l}\text { Acorus calamus } \\
L \text {. var. verus } L \text {. }\end{array}$ & $\begin{array}{l}\text { Wind, water } \\
\text { and earth }\end{array}$ & $\begin{array}{l}\text { Rhizome used for abdominal pain } \\
\text { and diarrhea, abdominal } \\
\text { distension, nausea and vomiting, } \\
\text { dizziness and headache, i } \\
\text { nsomnia and dreamful sleep, asthma. }\end{array}$ & $\begin{array}{l}\text { Soup of rhizome } \\
\text { obtained from decoction } \\
\text { to be taken orally. }\end{array}$ & $16(8.0)$ \\
\hline Jing Lang & $\begin{array}{l}\text { Nigella glandulifera } \\
\text { Freyn et Sint. }\end{array}$ & Wind and water & $\begin{array}{l}\text { Seed used for dizziness, headache, } \\
\text { insomnia and dreamful sleep, } \\
\text { postpartum bleeding, anemia, } \\
\text { hypogalactia, menoxenia, } \\
\text { menstrual colic, amenorrhea, } \\
\text { epilepsia, muscle and joint } \\
\text { pain, stomachache. }\end{array}$ & $\begin{array}{l}\text { Chewed seed to be } \\
\text { taken orally or smashed } \\
\text { seeds to be sniffed. }\end{array}$ & $15(7.5)$ \\
\hline Mi Huo Wa & $\begin{array}{l}\text { Tacca } \\
\text { chantrieri Andre' }\end{array}$ & Fire, water and wind & $\begin{array}{l}\text { Rhizome and leaf used for mumps, } \\
\text { submaxillary lymph nodes soreness, } \\
\text { galactophore soreness, sore throat, } \\
\text { cough, phlegm much, abdominal } \\
\text { pain and unknown toxin. }\end{array}$ & $\begin{array}{l}\text { Soup of rhizome or } \\
\text { leaf obtained from } \\
\text { decoction to be } \\
\text { taken orally. }\end{array}$ & $15(7.5)$ \\
\hline $\begin{array}{l}\text { Guo Long } \\
\text { Liang }\end{array}$ & Cassia fistula $\mathrm{L}$. & Wind and water & $\begin{array}{l}\text { Fruit, root, stem, bark and leaf used } \\
\text { for oppilation, dysuresia, urinary stones, } \\
\text { frequent and scanty urination } \\
\text { with continuous dripping, sore throat } \\
\text { due to heat-wind evils, orolingual furuncles, } \\
\text { tumor, headache, dizziness. }\end{array}$ & $\begin{array}{l}\text { Fruit to be chewed } \\
\text { and taken orally. } \\
\text { Soup of root, stem, bark } \\
\text { and leaf obtained from } \\
\text { decoction to be taken orally. }\end{array}$ & $14(7.0)$ \\
\hline Huang Giu & $\begin{array}{l}\text { Eclipta } \\
\text { prostrata (L.)L. }\end{array}$ & Water & $\begin{array}{l}\text { Whole herb used for dysentery, } \\
\text { abdominal pain, febrile convulsion, } \\
\text { skin and external diseases. }\end{array}$ & $\begin{array}{l}\text { Juice extracted from } \\
\text { whole herb to be taken } \\
\text { internally or applied } \\
\text { externally. }\end{array}$ & $13(6.5)$ \\
\hline Zhu Zha Ling & $\begin{array}{l}\text { Tinospora } \\
\text { sinensis (Lour.) Merr. }\end{array}$ & Water & $\begin{array}{l}\text { Vine used for insufficiency of } \\
\text { Qi and blood, general debility } \\
\text { and lassitude, palpitation, pain of } \\
\text { limbs and joints due to } \\
\text { wind-dampness evils, blood stasis } \\
\text { and swelling due to traumatic injury. }\end{array}$ & $\begin{array}{l}\text { Vine to be deposited } \\
\text { in alcohol or made into } \\
\text { powder and the alcohol } \\
\text { or powder to be taken orally. }\end{array}$ & $13(6.5)$ \\
\hline He Tao Leng & $\begin{array}{l}\text { Spatholobus } \\
\text { suberectus Dunn. }\end{array}$ & $\begin{array}{l}\text { Water, earth } \\
\text { and wind }\end{array}$ & $\begin{array}{l}\text { Vine used for dysmenorrhea, } \\
\text { amenorrhea, postpartum abdominal } \\
\text { pain, and anemia and to reduce } \\
\text { rheumatic pain and joint aches. }\end{array}$ & $\begin{array}{l}\text { Soup of vine obtained } \\
\text { from decoction to be } \\
\text { taken orally. }\end{array}$ & $12(6.0)$ \\
\hline
\end{tabular}


Table 4 Most commonly used medicinal plants (Continued)

\begin{tabular}{lllll}
\hline Bu Luei & $\begin{array}{l}\text { Zingiber } \\
\text { purpureum Rosc. } \\
\text { or Zingiber } \\
\text { corallinum Hance. }\end{array}$ & Earth & $\begin{array}{l}\text { Rhizome used for abdominal pain, } \\
\text { abdominal distension due to } \\
\text { food retention, nausea and } \\
\text { vomiting, hepatosplenomegaly, } \\
\text { arthralgia due to wind-heat. }\end{array}$ & $\begin{array}{l}\text { Soup of rhizome } \\
\text { obtained from } \\
\text { decoction or powder } \\
\text { of rhizome to be } \\
\text { taken orally. }\end{array}$ \\
\hline Ya La Meng & $\begin{array}{l}\text { Cassia obtusifolia L. } \\
\text { Hiam Leng }\end{array}$ & $\begin{array}{l}\text { Whole herb used for insomnia and } \\
\text { dreamful sleep, cramps, jaundice, } \\
\text { malaria, hepatitis. }\end{array}$ & $\begin{array}{l}\text { Soup of whole herb } \\
\text { obtained from decoction } \\
\text { to be taken orally. }\end{array}$ \\
& $\begin{array}{l}\text { Mahonia bealei } \\
\text { (Fort.) Carr. }\end{array}$ & $\begin{array}{l}\text { Earth } \\
\text { and water }\end{array}$ & $\begin{array}{l}\text { Stem used for jaundice, abdominal } \\
\text { distension, heat and pain, } \\
\text { dry mouth and throat, } \\
\text { diarrhea, orolingual sore, } \\
\text { irritability, menorrhagia. }\end{array}$ & $\begin{array}{l}\text { Soup of stem obtained } \\
\text { from decoction to be } \\
\text { taken orally or applied } \\
\text { externally. }\end{array}$ \\
\end{tabular}

the excesses or deficiencies of these elements in the body. For example, the diseases belonging to wind disorder are the most complex and extensive because wind can stimulate the human reproductive development, and promote metabolism, digestion and absorption of food and excretion. So, digestive system diseases, rheumatism and joint pain all belong to wind element disorders and can be cured by the herbs or prescriptions belonging to wind [6].

In Book A, 200 classic prescriptions are encompassed, including treatments of all four element disorders (8), wind disorders (40), fire disorders (40), water disorders (40), earth disorders (40), antidotes (16), and others (16). All prescriptions have more than one herb. Table 1 displays 11 selected prescriptions with the highest number of clinical indications, 5 of them belonging to antidote, 4 to wind element and 2 to fire attributions.

Table 2 shows the relationship between attributions and preparations. Decoction contributes more than $60 \%$ of all attributions, followed by powder (16.5\%), pill (8.4\%) and vinum (5.1\%). Other preparations accounted for less than $4 \%$. Wind was indicated in around a quarter of all preparations, followed by water (18.9\%). Sleeping on heated herbs is attributed to wind element disorder diseases only. Of all vinum preparations, wind disorders account for almost half of the attributions.

\section{Clinical indications, diseases and symptoms}

There were 277 clinical indications (111 diseases and 166 symptoms) mentioned in Book A. The most common indication (34.2\%) was digestive system diseases. As mentioned, both disorders and prescriptions belong to wind problems. As illustrated in Table 3, among the eighteen most common symptoms, eight symptoms are related to gastrointestinal problems. The explanation of why TDM is more commonly used for treating digestive system problems was not mentioned in the book.

Though we do not know how the editors of these textbooks bridge the gap between TDM and modern medicine, what is certain is that the philosophy of TDM is mainly symptomatic treatment. Some diseases, however, do not completely correspond with categorization of modern medicine. For example, in Book D, one disease called "Long Pi Le" by TDD includes all related woman's postpartum symptoms and diseases. Another disease called "Long Niu" includes all related diseases of urinary infection and urolithiasis [7]. This kind of classification deserves further investigation.

\section{Herb species identification and plant parts}

All ingredients mentioned in Book A have Dai names and/or Han names, and $70 \%$ of their botanical names could be identified in Book B which contain Han and Dai names as well as botanical names. Fourteen percent of the ingredients of prescriptions which could not be identified in Book B were available in a standard TCM book [8], while $12 \%$ could not be identified by any source. The remaining $4 \%$ were not herbs, and included honey, alcohol and chicken. TDD also adds various ingredients such as honey, rice wine, and rice-water as

Table 5 Medicinal parts of plants $(n=402)$

\begin{tabular}{lc}
\hline Medicinal part & Frequency (\%) \\
\hline Root & $349(38.2)$ \\
Whole herb & $179(19.6)$ \\
Stem & $111(12.2)$ \\
Seed & $55(6.0)$ \\
Fruit & $47(5.1)$ \\
Leaf & $43(4.7)$ \\
Bark & $40(4.4)$ \\
Pith & $14(1.5)$ \\
Flower & $20(2.2)$ \\
Latex & $12(1.3)$ \\
Bud & $11(1.2)$ \\
Other & $33(3.6)$ \\
Total & $914(100)$ \\
\hline
\end{tabular}

Note: the total is 914 because some herbs can be used in more than one medicinal part for medical purposes. 
supplementary substances when prescribing treatment as well as fresh herbal juices. For example: the juice of "Huang Giu" (Eclipta prostrata L.), one commonly used herb, can be used as a supplementary substance as well as a principal ingredient in a prescription as well.

The prescriptions involved 388 herbs, 11 animals and 3 minerals. One hundred and forty six items were only mentioned once, and nearly 90\% were used less than 6 times. The fifteen most commonly prescribed medicinal plants are listed in Table 4. The most commonly mentioned item was Biu Biu Liang (Plumbago indica Linn.) which appears in $24(12 \%)$ of the 200 prescriptions.

It was noted that underground plant parts, such as root, rhizome, tuber, groundnut and bulb, were all designated by a single term: "Ha" meaning root. The most commonly used plant part was the root accounting for $38.2 \%$, followed by whole herb (19.6\%) and stem (12.1\%). Other medicinal parts were used in less than $6 \%$ of plant parts. (Table 5)

\section{Dosage}

The same herb used in different prescriptions had different dosages. For example, the dosage of Biu Biu Liang varied from $5 \mathrm{~g}$ to $500 \mathrm{~g}$. The different dosages may indicate different roles of the same plant in different prescriptions.

\section{Conclusion}

Our analysis has summarized the nature of TDM theory which was expressed in prescriptions, attributions and indications. While commonly used herbs and their indications have been ascertained, the theories behind TDM need further studies.

\section{Limitations}

Han (Chinese) words used in the textbooks often have different pronunciation from Dai. Terms and concepts translated might be distorted by the influence of TCM prevailing in China.

\section{Competing interests}

The authors declare that they have no competing interests.

\section{Authors' contributions}

ZC collected and analyzed the data and wrote the manuscript. VC and ZC designed the study. VC, NK and YL supervised and provided comments on the draft of manuscript. All authors read and approved the final manuscript.

\section{Acknowledgments}

The authors would like to thank Mr. Somsawat Malathong for help in setting up the database, Mr. Edward McNeil and Dr. Alan Geater for the English revision. Special gratitude is expressed to Xishuangbanna Dai Medical Hospital for providing the textbooks and advice.

\section{Author details}

${ }^{1}$ Faculty of Ethnomedicine, Yunnan University of Traditional Chinese Medicine, No. 1076 Yuhua Road, Chenggong, Kunming, Yunnan Province 650500 , China. 'Epidemiology Unit, Faculty of Medicine, Prince of Songkla University, HatYai, Songkhla 90110, Thailand. ${ }^{3}$ Faculty of Pharmacy, Prince of
Songkla University, HatYai, Songkhla 90110, Thailand. ${ }^{4}$ Xishuangbanna Dai Medical Hospital, No.17 Minhang Road, JingHong, Yunnan 666100, China.

Received: 11 April 2012 Accepted: 26 August 2012

Published: 29 August 2012

\section{Reference}

1. Lin YF, Qiu MF, Jia W, et al: Overview of Chinese Dai Medical Research. $J$ Medicine \& Pharmacy of Chinese Minorities 2007, 10:1-5.

2. Hua L: Development and Utilization of Dai Traditional Medical Knowledge. The Ideological Front 1998, 10:63-67.

3. Gao M, Lee HK: The Transmission and modernization of Dai medical culture. J Medicine \& Pharmacy of Chinese Minorities 2008, 10:59-61.

4. Jia KL, et al: Formulas of Dai Medicine. Beijing, PRC: Traditional Chinese Medicine Press; 2007.

5. Zhu CL, Zhao YH, Ma WG, et al: Dai Materia Medica. Beijing, PRC: Traditional Chinese Medicine Press; 2007.

6. Zhang Ch YLB, Wang ZH, et al: Basic Theory of Dai Medicine. Beijing, PRC: Traditional Chinese Medicine Press; 2007.

7. Yang M, Zhang Ch YLB, et al: Diagnosis of Dai Medicine. Beijing, PRC: Traditional Chinese Medicine Press; 2007.

8. Teng JL, Li XG, Le YM, et al: Chinese Materia Medica. Beijing, PRC: People's Medical Publishing House; 2007.

\section{doi:10.1186/1746-4269-8-34}

Cite this article as: Zhang et al:: Analysis of prescription database extracted from standard textbooks of traditional Dai medicine. Journal of Ethnobiology and Ethnomedicine 2012 8:34.

\section{Submit your next manuscript to BioMed Central and take full advantage of:}

- Convenient online submission

- Thorough peer review

- No space constraints or color figure charges

- Immediate publication on acceptance

- Inclusion in PubMed, CAS, Scopus and Google Scholar

- Research which is freely available for redistribution 